JMLC

22,2

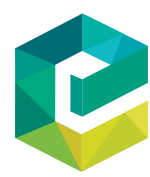

Journal of Money Laundering Control

Vol. 22 No. 2, 2019

pp. $270-288$

(c) Emerald Publishing Limited 1368-5201

DOI 10.1108/JMLC-03-2018-0019

\section{Exploring the role of risk and corruption on bank stability: evidence from Pakistan}

\author{
Muhammad Ali, Amna Sohail and Lubna Khan \\ Department of Business Administration, Iqra University, Karachi, Pakistan, and \\ Chin-Hong Puah \\ Department of Economics, Faculty of Economics and Business, \\ Universiti Malaysia Sarawak, Kota Samarahan, Malaysia
}

\begin{abstract}
Purpose - This paper aims to explore the impact of liquidity risk, credit risk, funding risk and corruption on bank stability of the banking system in Pakistan.

Design/methodology/approach - The empirical analysis is confined to 24 retail banks, which include 5 Islamic and 19 conventional banks during the period of 2007-2015.

Findings - The findings of this study suggest that bank size, liquidity risk, funding risk and corruption exert a positive impact on bank stability. Additionally, the authors find a negative relationship between credit risk and bank stability.
\end{abstract}

Originality/value - As per the knowledge of the authors, the present research is the first attempt that discusses the issues of bank stability related to risk and corruption faced by the banking system.

Keywords Liquidity risk, Corruption, Credit risk, Bank stability, Funding risk

Paper type Research paper

\section{Introduction}

Bank stability relates as a situation where the financial intermediation offered by the banking sector works efficiently and continues without any disturbance despite any internal or external shock. According to the State Bank of Pakistan (SBP), financial stability is a gradual process, and it depends on the ability of the banking sector to understand the needs of the economy. A stable banking system has several implications such as, enhancement of economic growth, efficient financial intermediation, public well-being, investment patterns, competition and others. Banking sector stability also stems the confidence of economic agents in the financial system. In general, the state bank of a country primarily administers the soundness of financial sector that ultimately plays a significant role in determining the growth and development of the banking sector.

Moreover, commercial banks are closely associated with business models, consumer operations and other economic activities. It includes monthly salaries, deposit mobilization, consumer finance and borrowing money for consumption or investment purpose. In this context, past studies have highlighted the role of the banking sector to predict efficient business environment (Beck and Levine, 2004; Wilhelm, 2002). Similarly, an efficient banking system is also necessary for the businesses due to their involvement in banking transactions. On the same vein, Da Rin and Hellmann (2002) state that the banking sector has key role to strengthen industrialization in the developing economies. However, the instability in the banking sector can cause large disruption in the society and economic growth. 